Bangladesh J. Sci. Ind. Res. 42(2), 175-186, 2007

\title{
Efeect of Sulphur, Bradyrhizobium Inoculation, Initial Moisture Content of Seed and Storage Container on the Germination Percentage of Groundnut Seed
}

\author{
M. Ataur Rahman \\ Department of Agronomy, Hajee Mohammad Danesh Science and \\ Technology University, Dinajpur- 5200, Bangladesh.
}

\begin{abstract}
The study was aimed at determining the effect of sulphur and Bradyrhizobium fertilized seed at different initial moisture content of seed and storage container, to improving the germination percentage of groundnut seed. The germination test was carried out after storing the seed for five months. Results revealed that seeds obtained from $60 \mathrm{~kg} \mathrm{~S} / \mathrm{ha}$. stored in polythene bags retained the germination percentage up to the standard level of ISTA for 5 months efficiently. Least initial moisture content of seed (7.25 \%) produced from the above doses of fertilizer elements also played a vital role in keeping the quality of stored seed. Results in the respect of storage performance in terms of percentage of germination indicated that groundnut seed obtained from sulphur and Bradyrhizobium fertilizer elements during production and stored in polythene bag can retain better seed quality, provided seed were dried to a safe moisture level of $7.25 \%$ to $8.46 \%$.
\end{abstract}

\section{Introduction}

Sulphur has long been recognized as an essential nutrient elements for plants and it ranks in importance with nitrogen and phosphorous. the legume oilseed crops are more susceptible for sulphur deficiency due to their higher requirement. Since groundnut is a legume crop it is quite likely that it may respond to sulphur. Sulphur also plays a vital role in the longevity of seed in storage and better performance of seedling in the field. Sulphur is a component element of proteins, sulpholipids, enzymes etc.
Seed moisture content is regarded as the most important factor that impairs seed quality at storage. The metabolic activities of stored seed are dependent on the absolute seed moisture content. Moreover, it helps to establish relative humidity surrounding seeds, which in turn influences microbial growth in the seed lot. This does not apply only to the absolute moisture content of the seeds, but also to the fluctuation of moisture depending on the relative humidity from the immediate atmosphere and type of storage container. Therefore, to achieve good survival at stor- 
age, reduction of seed moisture content to a suitable level through drying is of paramount importance (Harringtor and Minges, 1973).

Storage condition plays a significant role in seed preservation, Storage containers of semi-permeable to non-permeable status may be of note worthy for short-term as well as long-term seed perservation. Seed growers at farm level use various containers but most of them are not conducive to seed health because of permeable in nature. Under high humid condition, permeable containers allow moisture penetration, which in turn increases humidity surround the seeds. Seeds with presence of excess moisture and with the rise of ambient temperature during summer months tend to germinate at storages even with the absence of other conditions required for seed germination. In this process, seeds gradually lose vigour and evemtually complete destruction of viability . Once there grows tendency of germination in seeds at storage, these seeds deceive germination second time in the field.

The storage potential of groundnut seeds depends on the genetic make up of each groundnut line, initial seed germ inability and vigour. Viability of stored groundnut seeds in both traditional and improved containers was found to decrease with passage of time. Seed quality, especially germination, is essential to establish adequate plant stand for crop production (Bhuiyan and Quashem, 1983). Seed quality can be adversely affected by the environmental factors. Seed storage throughout the hot-humid season mainly for carry-over seeds becomes a chronic problem. Subsistent seed growers cannot afford costly storage containers. It is imperative to indentify cheap and handy containers that would be used safely for long-term seed preservation. Information in these aspects is almost lacking in Bangladesh. This basic information is very much essential for improvement of overall management practices of groundnut seed crop. Therefore, the present study was designed with the objectives to find out the performance of sulphur and Bradyrhizobium fertilization, initial moisture content of seed and storage container on the of germination percentage.

\section{Materials and Methods}

To find out the germination percentage the following parameters were used :

A. Sulphur : Five dose of sulphur, .i. $0 \mathrm{~kg} / \mathrm{ha}$ S up to v. $80 \mathrm{~kg} / \mathrm{ha} S$ viz. i. $0 \mathrm{~kg} / \mathrm{ha} S$ ii. 20 $\mathrm{kg} / \mathrm{ha} S$ iii. $40 \mathrm{~kg} / \mathrm{ha} S$ iv. $60 \mathrm{~kg} / \mathrm{ha} \mathrm{S} \mathrm{v.} 80$ $\mathrm{kg} / \mathrm{ha}$ S.

B. Bradyrhizobium fertilization : Two dose of inoculation viz inoculation@.i. 0 g I/kg of seed and ii. $50 \mathrm{~g} \mathrm{I} / \mathrm{kg}$ of seed were applied to the groundnut seed before sowing.

C. Initial moisture content of seed L Three treatmeents were selected. The treatments were

i. $7.25 \%$ initial moisture content of seed

ii. $8.46 \%$ initial moisture content of seed

iii. $9.25 \%$ initial moisture content of seed 
D. Storage container : Two treatments were chosen as storage containers.

i. Biscuit tin with air tight lid.

ii. Polypropylene bag with $0.25 \mathrm{~mm}$ thicknes.

Sulphur doses were 5, Bradyrhizobium fertilization doses were 2, initial moisture content of seed level was 3 and storage container were 2. The experiment was set combining the treatment following the principles of Complete Randomized Design with three replication. The germination percentage data were collected were collected from each test and analyzed through a statistical computer programme M STAT-C. When the F value was sighnificant, Least Significance Difference was used as a scale to distinguish between the different means. During analysis arc-sine transformation was made in case of germination percentagde.

\section{Germination test}

The germination test was performed at intervals of one-month starting from August to December in 1998 and 1999. A total number of 400 seeds were set for germination in 16 Petri dishes each containing 25 seeds. Filter paper was used as media of germination. The Petri dish was kept at normal room temperature. germinated seedlings were made at 3, 5 and 7 days after placing seeds for germination. Percentage of germination was measured by the following formula :

$\%$ Germination $=$

No. of normal seedling

Total no. of seed set for germination

\section{Results and Discussion}

Effect of sulphur, inoculation, initial moisture content of seed and storage container on the germination percentage of stored seed

A. Sulphur did not affect the germination percentage of seed at 1 month interval in 1997-98 indicating that deterioration of stored seed had not yet been started (Table I). At an interval of 2 months, the effect of sulphur on the germination percentae of seed was significant and the highest percentage of germiation was obtained in $60 \mathrm{~kg} \mathrm{~S} / \mathrm{ha}$ and the lowest in control. At an interval of 3 and 4 months, the effect of sulphur on the germination percentage of stored seed was also significant and the trend was similar to that of 2 months interval. At an interval of 5 months, the effect of sulphur was significant. In addition to that 40 and $80 \mathrm{~kg} \mathrm{~S} /$ ha retained identical percentage of germination. The highest and the lowest percentage of germination were obtained by 60 and $0 \mathrm{~kg} \mathrm{~S} / \mathrm{ha}$, respectively. In 1998-99, at an interval of 1month the effect of sulphur on the germination percentage of seed was significant. At an interval of 2 months, the seed of the treatment 60, 80 and $40 \mathrm{~kg} \mathrm{~S} /$ ha produced at par percentage of germination. At an interval of 3 months, $60 \mathrm{~kg}$ S/ha retained significantly higher and $0 \mathrm{~kg} \mathrm{~S} /$ ha lower percentage of germination. The treatments 80,40 and $20 \mathrm{~kg}$ $\mathrm{S} /$ ha retained identcal percentage of germination (Table I). From the above results it was clear that doses of sulphur increased the germination retention capacity of seed up to $60 \mathrm{~kg} \mathrm{~S} / \mathrm{ha}$ and higher doses of sulphur 
beyond it had no impact on the germination percentage of stored seed. Juangjum and Sumran (1991) obtained similar results. The data were plotted in the graphs (Fig. 1 and 2) showed the clear trend of deterioration in germination percentage of sulphur treated stored seed.
B. The effect of inoculation of seed with Bradyrhizobium at an interval of 1 month was not significant in 1997-98 (Table I). From the interval of 2 months the inoculated seed reatained significantly superior percentage of germination over uninoculated one and these results continued up to 5 month

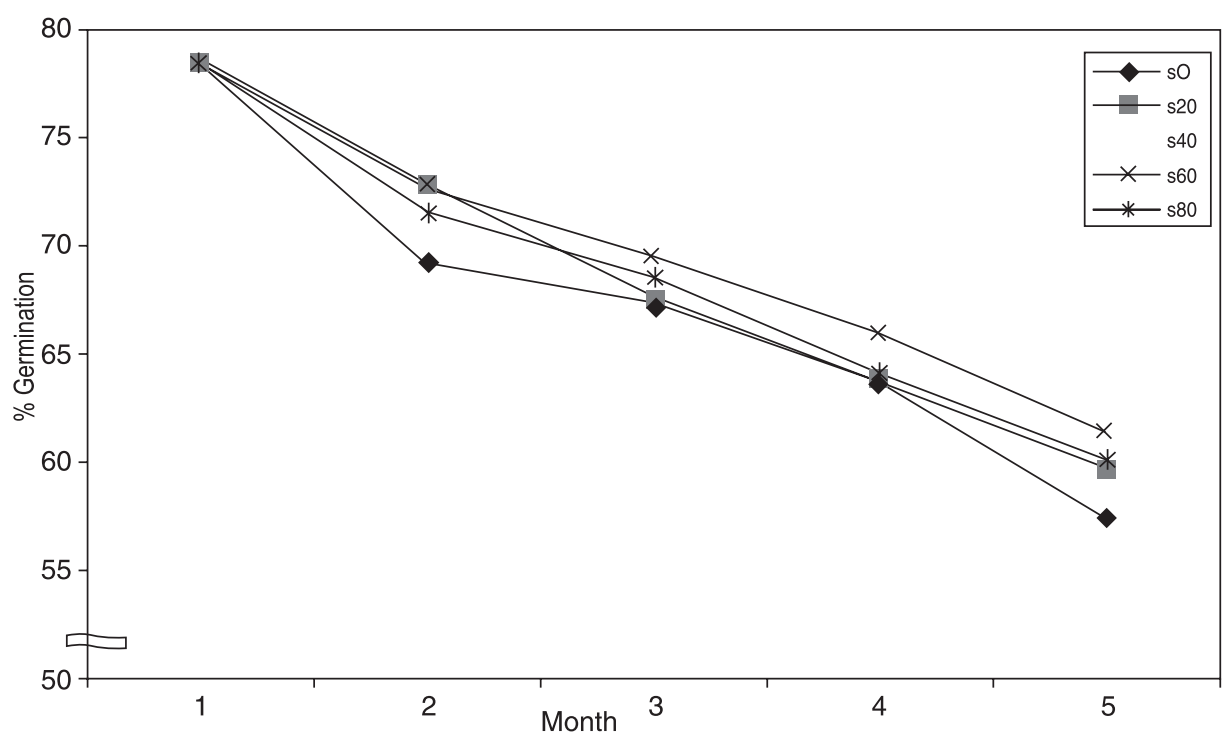

Fig. 1. Effect of sulphur on the germination percentage of stored seed in 1997-98

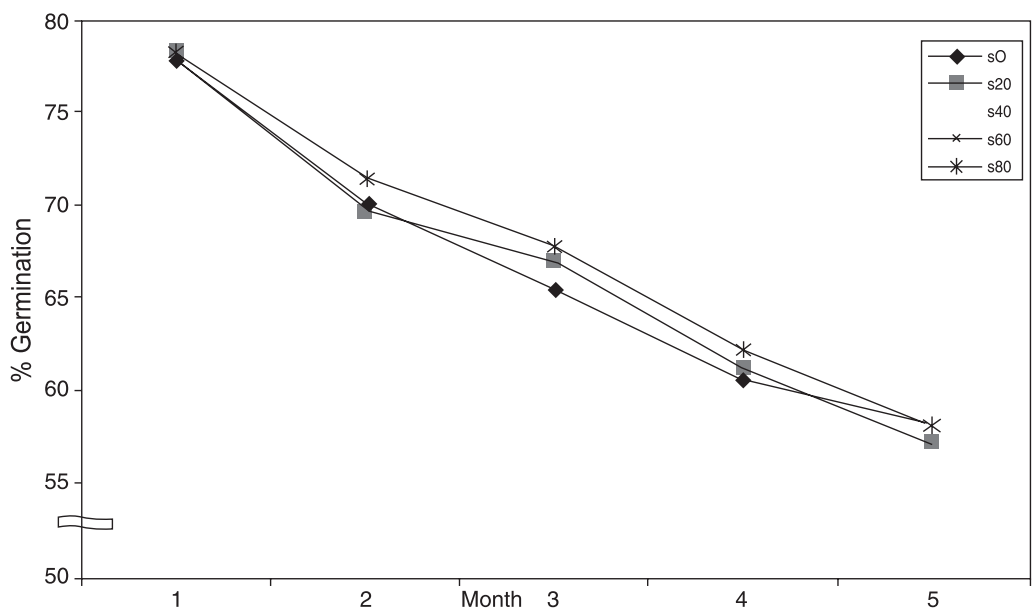

Fig. 2. Effect of sulphur on the \% of germination of stored seed in 1999-99 
Table I. Germination percentage of seed over storage period as affected by sulphur level, inoculation, storage container and moisture level

\begin{tabular}{|c|c|c|c|c|c|c|c|c|c|c|}
\hline \multirow[t]{2}{*}{ Treatment } & \multicolumn{5}{|c|}{$1997-98$} & \multicolumn{5}{|c|}{ 1998-99 } \\
\hline & 1 month & 2 month & 3 month & 4 month & 5 month & 1 month & 2 month & 3 month & 4 month & 5 month \\
\hline \multicolumn{11}{|l|}{ S level } \\
\hline $\mathrm{S}_{0}$ & 77.57 & 67.98 & 64.96 & 59.85 & 55.47 & 77.90 & 69.99 & 65.45 & 60.71 & 58.03 \\
\hline $\mathrm{S}_{20}$ & 77.53 & 69.95 & 65.90 & 60.89 & 56.39 & 78.26 & 69.70 & 66.83 & 60.99 & 57.01 \\
\hline $\mathrm{S}_{40}$ & 77.50 & 71.13 & 66.67 & 61.87 & 57.29 & 78.18 & 71.08 & 67.58 & 62.14 & 58.09 \\
\hline $\mathrm{S}_{60}$ & 77.91 & 72.16 & 68.04 & 62.84 & 58.67 & 78.49 & 72.32 & 68.84 & 62.88 & 59.28 \\
\hline $\mathrm{S}_{80}$ & 77.48 & 69.32 & 65.90 & 60.73 & 57.02 & 78.27 & 71.37 & 67.76 & 62.12 & 57.97 \\
\hline LSD (0.05) & NS & 0.389 & 0.345 & 0.454 & 0.358 & 0.417 & 0.389 & 0.961 & 0.736 & 0.976 \\
\hline \multicolumn{11}{|l|}{ Inoculation } \\
\hline $\mathrm{I}_{0}$ & 77.62 & 69.79 & 66.11 & 61.08 & 56.84 & 78.19 & 70.86 & 67.05 & 61.58 & 58.04 \\
\hline$\underline{I}_{5} 0$ & 77.58 & 70.43 & 66.48 & 61.40 & 57.09 & 78.24 & 70.93 & 67.53 & 61.96 & 58.36 \\
\hline LSD (0.05) & NS & 1.347 & 1.94 & 1.574 & 1.238 & NS & NS & NS & NS & NS \\
\hline \multicolumn{11}{|c|}{ Storage condition } \\
\hline $\mathrm{Sc}_{1}$ & 77.21 & 69.32 & 64.76 & 58.87 & 54.00 & 78.18 & 68.39 & 65.39 & 59.95 & 55.77 \\
\hline $\mathrm{Sc}_{2}$ & 77.99 & 70.90 & 67.82 & 63.60 & 59.94 & 78.25 & 72.83 & 69.20 & 63.59 & 60.62 \\
\hline LSD (0.05) & NS & 1.347 & 1.494 & 1.574 & 1.238 & NS & 3.68 & 3.328 & 2.549 & 3.381 \\
\hline \multicolumn{11}{|c|}{ Moisture level } \\
\hline $\mathrm{Ml}_{1}$ & 78.19 & 72.92 & 68.73 & 65.19 & 62.12 & 78.85 & 73.94 & 70.72 & 65.27 & 63.05 \\
\hline $\mathrm{Ml}_{2}$ & 77.64 & 70.23 & 66.11 & 61.75 & 57.46 & 78.14 & 70.54 & 67.10 & 61.71 & 58.89 \\
\hline $\mathrm{Ml}_{3}$ & 76.97 & 67.18 & 64.04 & 56.78 & 51.32 & 77.66 & 68.19 & 64.06 & 58.33 & 52.64 \\
\hline LSD (0.05) & 0.297 & 0.824 & 0.267 & 0.352 & 0.277 & 0.323 & 0.301 & 0.744 & 0.570 & 0.567 \\
\hline
\end{tabular}

intervals in storage. In 1997-98 the inoculation treatment did not affect the germination percentage of stored seed significantly. The results indicate that germination percentage of stored seed was improved with the application of inoculation.

C. The initial moisture content of the seed affected significantly the germination percentage of seed from 2 month interval in 1997-98 (Table I). The highest percentage of germination was retained by the treatment of $7.25 \%$ initial moisture while the lowest percentage of germination was obtained in 9.25\% initial moisture content and $8.25 \%$ initial moisture content retained intermediate level of germination. Similar results were also obtained in the entire 4 months interval. In 1998-99, the effect of initial moisture content was at par (Table I). The results indicated that the initial moisture content of the seed was very important for retaining germination percentage of seed. The data were plotted in the graphs (Fig. 5 and 6) showed the trend of deterioration in germination per centage of stored seed at different level of 
initial moisture content as the duration of seed in storage lingered. Paungthong and Lamduan (1987) obtained similar results.
D. The container affected the germination percentage of stored seed significantly in 1997-98 and 1998-99 except at an interval of

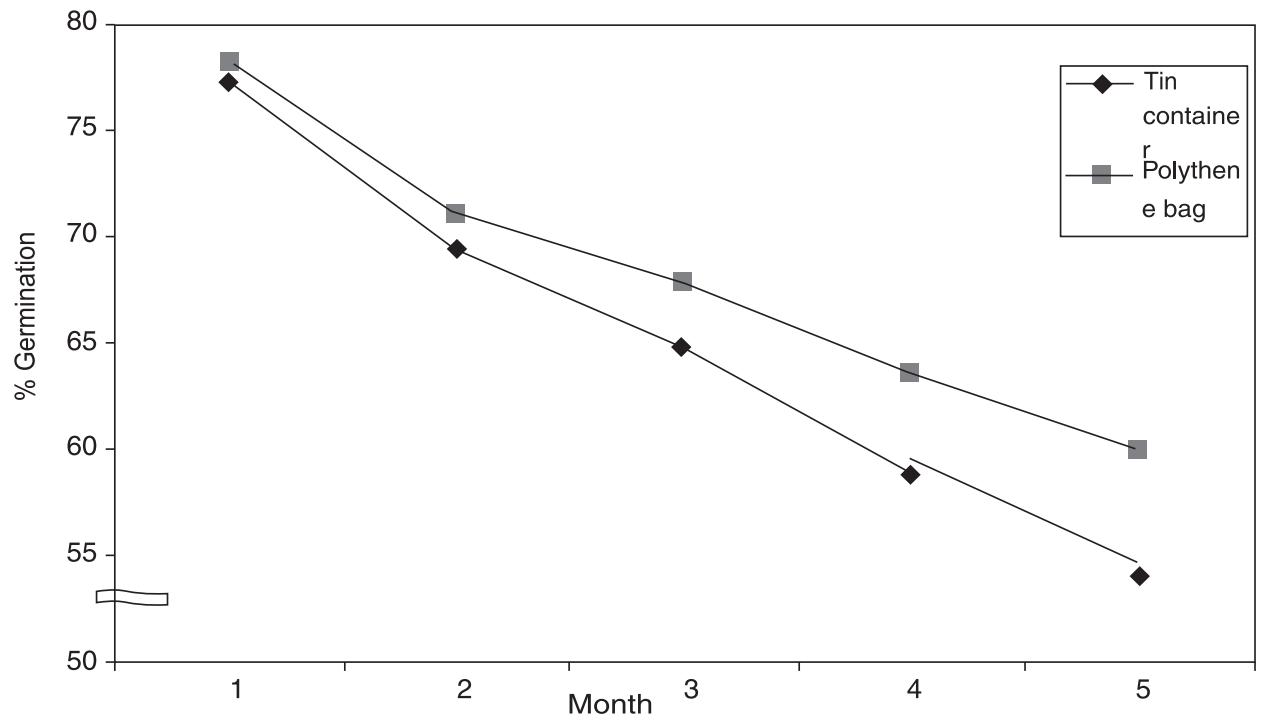

Fig. 3. Effect of storage container on the \% of germination of stored seed in 1997-98

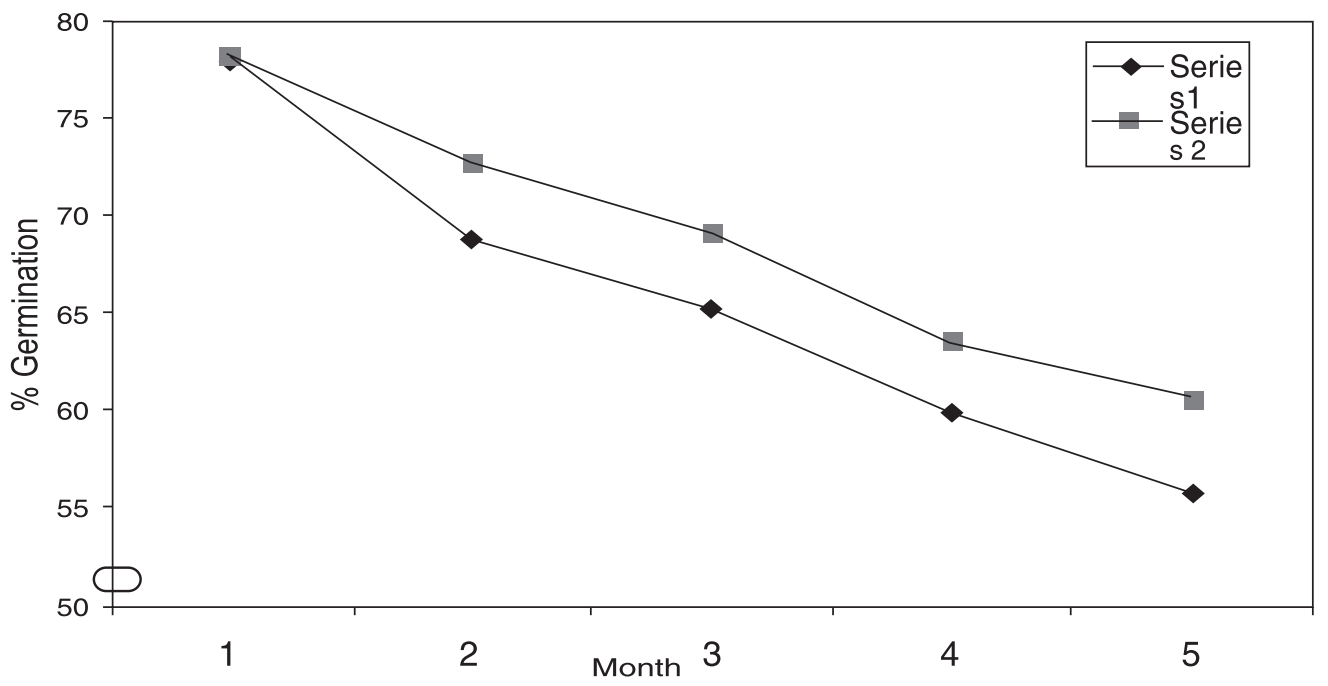

Fig. 4. Effect of storage container on the germination percentage in 1998-99 
1 month in 1997-98 (Table I). In all the intervals plastic bags retained significantly higher percentage of germination over tin container. The data were plotted in the graphs and the figure (Fig.3 and 4) showed the clear trend of deterioration in germination percentage of seed stored in different container. Similar results were obtained by Paungthong et al. (1990) and Vichai, et al. (1988).

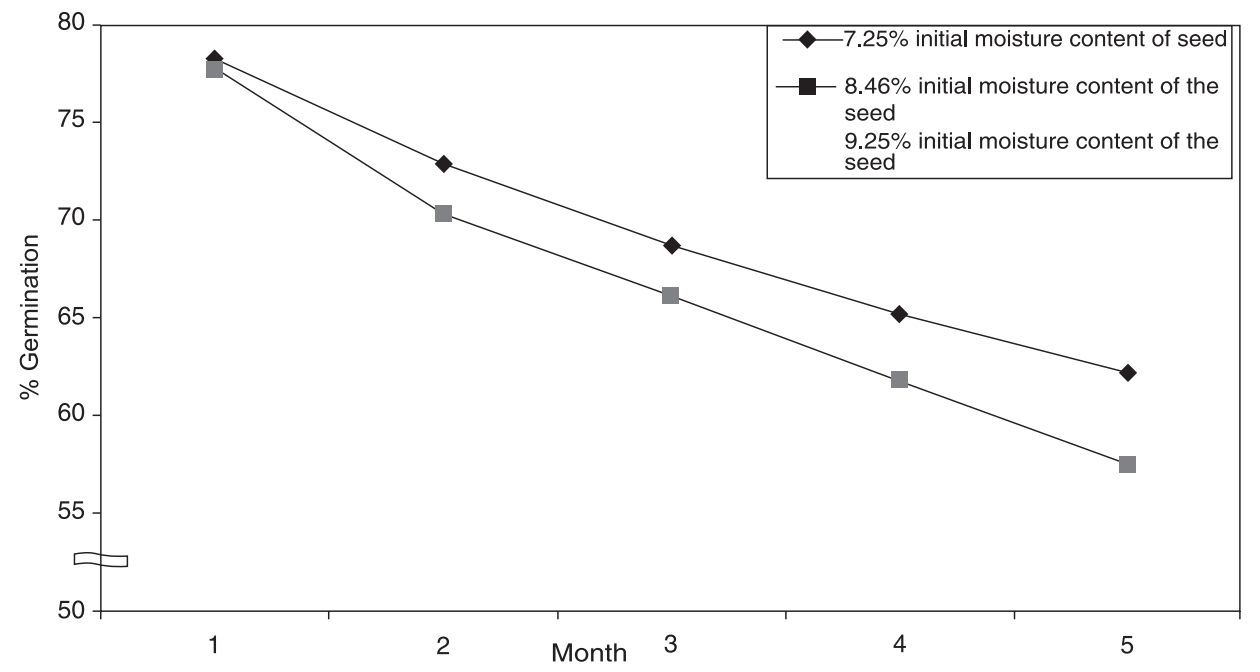

Fig. 5. Effect of initial moisture content of the seed on the \% of germination of stored seed in 1997-98

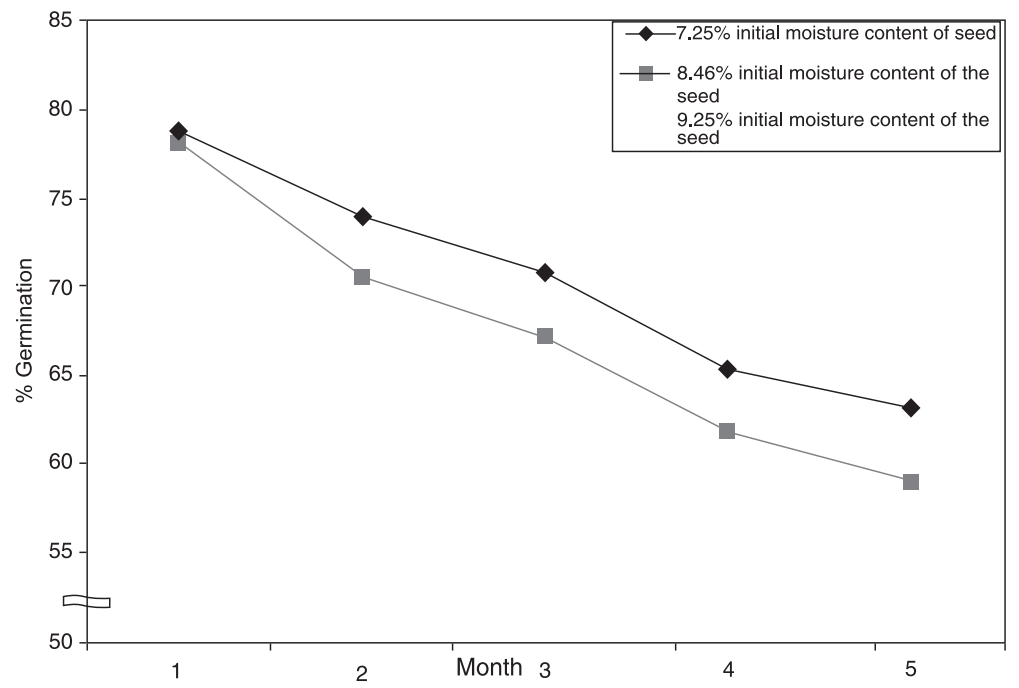

Fig. 6. Effect of initial moisture content of the seed on the \% of germination of stored seed in 1998-99 
Interaction of sulphur and inoculation of bradyrhizobium on the germination percentage of stored seed

The interaction of sulphur and inoculation was not significant in 1997-98 and 1998-99.

Interaction of sulphur and storage container on the germination percentage of stored seed

The interaction of sulphur and storage container was not significant on the percentage of germination in 1997-98 and 1998-99.

Interaction of inoculation and storage container on the germination percentage of stored seed

Interaction of inoculation and storage container was not significant in 1997-98 and 1998-99 but inoculated or un-inoculated seeds in polythene bag retained high percentage of germination over un-inoculated seed kept in tin container. It is evident from the results that polythene bags can retained the standard germination percentage of seed up to 5 months of storage and after that lost the capacity to retain the germination capacity of seed up to standard level. The results are in partial fulfillment with Jayaraj and Karivaratharaju (1988).

Interaction of sulphur, inoculation and storage container on the germination percentage of stored seed

The interaction of sulphur, inoculation and storage container was not sitnificant in 199798 and 1998-99. The germination percentage obtained in the treatment $60 \mathrm{~kg} \mathrm{~S} / \mathrm{ha}$ with or without inoculation and kept in polythene bags was highest. Seeds with higher doses of sulphur up to optimum level retained superior percentage of germination. The lowest percentage of germination was retained by control. It was evident that doses of sulphur and polythene bags container were the main key of storage life of stored groundnut seed while inoculation can retain better life of seed at early stage of storage only.

Interaction of sulphur and initial moisture level of seed on the germination percentage of stored seed

Seeds with higher dose of sulphur up to $60 \mathrm{~kg}$ /ha and low initial moisture content retained higher precentage of germination in 1997-98 and 1998-99 (Table II).

At an interval of 2 months, seeds with $60 \mathrm{~kg}$ S/ha and with initial moisture content of 7.2\% retained significantly higher prtecentage of germination over other treaments. The lowest precentage of germination was retained by $0 \mathrm{~kg} \mathrm{~S} / \mathrm{ha}$ with initial moisture content of $9.25 \%$ At an interval of 3 month similar results wre also obtained.

Interaction of inoculation and initial moisture content of the seed on the germination percentage of stored seed

The interaction of inoculation and initial moisture content was not significant al all the intervals in 1997-98 and 1998-99. The results are in partial agreement with Jayaraj and Karivarathatraju (1988). 
Table II. Interaction of sulphur and initial moisture content of seed on the germination percentage of stored seed

\begin{tabular}{l|c|c|c|c|c|c|c|c|c|c}
\hline Treatment & \multicolumn{5}{|c|}{$1997-98$} & \multicolumn{5}{c}{$1998-99$} \\
\hline SxM.level & 1 month & 2 month & 3 month & 4 month & 5 month & 1 month & 2 month & 3 month & 4 month & 5 month \\
\hline $\mathrm{S}_{0} \times \mathrm{Ml}_{1}$ & 70.46 & 70.46 & 67.27 & 63.85 & 60.49 & 78.43 & 72.54 & 69.34 & 64.59 & 62.31 \\
$\mathrm{~S}_{0} \times \mathrm{Ml}_{2}$ & 77.55 & 68.04 & 64.83 & 60.32 & 56.09 & 77.86 & 69.78 & 65.33 & 60.33 & 58.06 \\
$\mathrm{~S}_{0} \times \mathrm{Ml}_{3}$ & 77.08 & 65.45 & 62.78 & 55.38 & 49.83 & 77.40 & 67.67 & 61.98 & 57.21 & 50.67 \\
$\mathrm{~S}_{20} \times \mathrm{Ml}_{1}$ & 78.10 & 72.56 & 68.51 & 64.87 & 61.38 & 78.82 & 72.73 & 69.95 & 64.46. & 63.02 \\
$\mathrm{~S}_{20} \times \mathrm{Ml}_{2}$ & 77.64 & 70.01 & 65.59 & 61.39 & 56.93 & 78.09 & 69.12 & 66.66 & 61.11 & 58.72 \\
$\mathrm{~S}_{20} \times \mathrm{Ml}_{3}$ & 76.85 & 67.28 & 63.60 & 56.42 & 50.84 & 77.87 & 67.24 & 63.87 & 57.41 & 52.52 \\
$\mathrm{~S}_{40} \times \mathrm{Ml}_{1}$ & 78.10 & 74.13 & 69.38 & 65.38 & 62.42 & 78.69 & 74.25 & 71.00 & 65.57 & 63.81 \\
$\mathrm{~S}_{40} \times \mathrm{Ml}_{2}$ & 77.62 & 71.32 & 66.30 & 62.61 & 57.69 & 77.99 & 70.79 & 67.63 & 62.21 & 59.15 \\
$\mathrm{~S}_{40} \times \mathrm{Ml}_{3}$ & 76.78 & 67.95 & 64.33 & 57.65 & 51.78 & 77.86 & 68.21 & 64.11 & 58.63 & 52.95 \\
$\mathrm{~S}_{60} \times \mathrm{Ml}_{1}$ & 78.58 & 75.40 & 70.89 & 67.24 & 64.18 & 79.38 & 76.23 & 72.75 & 66.19 & 64.04 \\
$\mathrm{~S}_{60} \times \mathrm{Ml}_{2}$ & 77.57 & 72.37 & 67.70 & 63.25 & 58.86 & 78.46 & 71.86 & 68.47 & 63.00 & 59.97 \\
$\mathrm{~S}_{60} \times \mathrm{Ml}_{3}$ & 77.41 & 68.72 & 65.52 & 58.02 & 52.98 & 77.64 & 68.85 & 65.30 & 59.45 & 53.83 \\
$\mathrm{~S}_{80} \times \mathrm{Ml}_{1}$ & 78.08 & 72.05 & 67.63 & 64.59 & 62.12 & 78.95 & 73.95 & 70.83 & 65.52 & 62.10 \\
$\mathrm{~S}_{80} \times \mathrm{Ml}_{2}$ & 77.62 & 69.44 & 66.11 & 61.17 & 57.75 & 78.33 & 71.18 & 67.43 & 61.90 & 58.56 \\
$\mathrm{~S}_{80} \times \mathrm{Ml}_{3}$ & 76.74 & 66.47 & 63.97 & 56.41 & 51.18 & 77.52 & 68.99 & 65.02 & 58.93 & 53.24 \\
\hline $\left.\mathrm{LSD}_{0} 0.05\right)$ & NS & 0.674 & 0.597 & NS & NS & NS & NS & NS & NS & NS \\
\hline
\end{tabular}

Interaction of sulphur, inoculation and initial moisture content of the seed on the germination percentage of stored seed

The interaction of sulphur, inoculation and initial misuter content of the seed was not significant in 1997-98 and 1998-99. The highest germination precentage was retained by the treatment $60 \mathrm{~kg} \mathrm{~S} / \mathrm{ha}$ with inoculation and $7.25 \%$ initial moisture content of the seed in both the years. The lowest germination precentage was obtained by the treatment $\mathrm{O}$ kg S/ha with inoculation and 9.25\% initial moisture content.
Interaction of storage container and initial moisture content of the seed on the germination percentage of stored seed

The interaction of storage container and initial moisture content of the seed was significant (Table III). In 1997-98, seed with $7.25 \%$ initial moisture and stored in polythene bag retained the highest precentage of germination and the lowest precentage of germination were in seeds kept in tin container and with $9.25 \%$ initial moisture content. From the interval of 3 months, the seed with different initial moisture level stored in polythene bags retained higher precentage of 
Table III. Interaction of storage container and initial moisture content of the seed on the germination percentage of stored seed

\begin{tabular}{c|c|c|c|c|c|c|c|c|c|c}
\hline Treatment & \multicolumn{5}{|c|}{$1997-98$} & \multicolumn{5}{c}{$1998-99$} \\
\hline $\begin{array}{c}\text { St. conditon } \\
\text { x M.level }\end{array}$ & 1 month & 2 month & 3 month & 4 month & 5 month & 1 month & 2 month & 3 month & 4 month & 5 month \\
\hline $\mathrm{Sc}_{1} \times \mathrm{Ml}_{1}$ & 77.74 & 72.11 & 66.51 & 63.17 & 59.68 & 78.75 & 71.08 & 67.81 & 65.51 & 59.90 \\
$\mathrm{Sc}_{1} \times \mathrm{Ml}_{2}$ & 77.35 & 69.54 & 64.81 & 60.66 & 54.54 & 78.31 & 68.73 & 65.50 & 60.71 & 57.17 \\
$\mathrm{Sc}_{1} \times \mathrm{Ml}_{3}$ & 76.56 & 66.32 & 62.97 & 52.80 & 47.78 & 77.48 & 67.07 & 62.85 & 56.92 & 50.26 \\
$\mathrm{Sc}_{2} \times \mathrm{Ml}_{1}$ & 78.64 & 73.73 & 70.96 & 67.21 & 64.55 & 78.96 & 76.80 & 73.62 & 68.03 & 66.21 \\
$\mathrm{Sc}_{2} \times \mathrm{Ml}_{2}$ & 77.93 & 70.93 & 67.40 & 62.84 & 60.39 & 77.98 & 72.37 & 68.71 & 63.02 & 60.61 \\
$\mathrm{Sc}_{2} \times \mathrm{Ml}_{3}$ & 77.39 & 68.04 & 65.11 & 60.76 & 54.86 & 77.84 & 69.32 & 65.26 & 59.73 & 55.03 \\
\hline $\mathrm{LSD}(0.05)$ & $\mathrm{NS}$ & $\mathrm{NS}$ & 0.378 & 0.498 & 0.392 & 0.420 & 1.165 & 1.053 & 0.806 & 3.381 \\
\hline
\end{tabular}

germination oven seeds same initial moisture content but sotored in tin container. At an interval of 4 months, the seeds with $7.25 \%$ initial moisture content and kept in tin container retained identical precentage of germination with seeds with $8.46 \%$ initial moisture content and kept in polythene bags. A similar result was also obtained in 1998-99. At an interval of 5 months in 1998-99 in 1998-99, the results were at par to months interval but in 1997-98 the seeds with defferent initial moisture content and storage container retained significantly different germination percentage. The above results indicated that seeds with higher initial moisture content and kept in polythene bags can retaiend the germination precentage longer than seeds kept in tin containers with low initial moisture content. Prasat and Chaumsri (1987) obtained similar results.
Interaction of sulphur, storage container and initial moisture content on the germination percentage of stored seed

In 1997-98 at an interval of 2 months, the seeds with $60 \mathrm{~kg} \mathrm{~S} / \mathrm{ha}$ and initial moisture content $(7.25 \%$ and jept in polythene bags rerained significantly superior percentage of germination which retained at par germination percentage with $40 \mathrm{~kg} \mathrm{~S} / \mathrm{ha}$ and $7.25 \%$ initial moisture content and kept in polythene bage (Table IV).

In 1998-99, the seeds with initial moisture content of $7.25 \%$ and kept in polythene bags with different levels of sulphur in control retained significantly superior percentage of germination and other retained identical percentage of germination. Puangthong et al. (1990) found similar results. The interaction of inoculation, storage container and initial moisture content of seed was not significant in 1997-98 and 1998-99. The lowest 
Table IV. Interaction of sulphur, storage container and initial moisture content on the germination percentage of stored seed

\begin{tabular}{|c|c|c|c|c|c|c|c|c|c|c|}
\hline \multirow{2}{*}{\begin{tabular}{l|} 
Treatment \\
Sulp.xSt.con \\
xMoist. level \\
\end{tabular}} & \multicolumn{5}{|c|}{ 1997-98 } & \multicolumn{5}{|c|}{ 1998-99 } \\
\hline & 1 month & 2 month & 3 month & 4 month & 5 month & 1 month & 2 month & 3 month & 4 month & 5 month \\
\hline $\mathrm{S}_{0} \times \mathrm{Sc}_{1} \times \mathrm{Ml}_{1}$ & 77.74 & 70.45 & 65.26 & 61.66 & 58.03 & 78.43 & 67.60 & 65.38 & 64.50 & 58.67 \\
\hline${ }_{0} \times \mathrm{Sc}_{1} \times \mathrm{Ml}_{2}$ & 77.09 & 66.80 & 63.65 & 59.32 & 53.41 & 78.43 & 66.18 & 65.30 & 60.44 & 53.01 \\
\hline${ }_{0} \times \mathrm{Sc}_{1} \times \mathrm{Ml}_{3}$ & 76.65 & 64.50 & 61.55 & 51.43 & 45.75 & 78.43 & 61.21 & 57.50 & 57.44 & 46.89 \\
\hline $\mathrm{S}_{0} \times \mathrm{Sc}_{2} \times \mathrm{Ml}_{1}$ & 78.43 & 70.46 & 69.27 & 66.03 & 62.94 & 78.43 & 73.74 & 72.39 & 64.68 & 65.39 \\
\hline${ }_{0} \times \mathrm{Sc}_{2} \times \mathrm{Ml}_{2}$ & 78.00 & 69.28 & 66.01 & 61.32 & 58.78 & 78.43 & 72.95 & 71.26 & 60.22 & 61.57 \\
\hline${ }_{0} \mathrm{xSc}_{2} \times \mathrm{Ml}_{3}$ & 77.51 & 66.40 & 64.01 & 59.34 & 53.91 & 78.43 & 72.20 & 61.90 & 56.99 & 53.44 \\
\hline${ }_{20} \times \mathrm{Sc}_{1} \times \mathrm{Ml}_{1}$ & 77.51 & 71.71 & 66.41 & 62.82 & 59.00 & 78.43 & 68.71 & 66.54 & 63.66 & 61.78 \\
\hline $\mathrm{S}_{20} \times \mathrm{Sc}_{1} \times \mathrm{Ml}_{2}$ & 77.09 & 69.57 & 64.51 & 60.42 & 54.12 & 78.43 & 68.51 & 67.52 & 60.66 & 57.94 \\
\hline $\mathrm{S}_{20} \times \mathrm{Sc}_{1} \times \mathrm{Ml}_{3}$ & 76.42 & 66.40 & 62.59 & 52.81 & 47.37 & 78.43 & 62.16 & 59.13 & 57.20 & 49.39 \\
\hline $\mathrm{S}_{20} \times \mathrm{Sc}_{2} \times \mathrm{Ml}_{1}$ & 78.69 & 73.41 & 70.61 & 66.92 & 63.77 & 78.43 & 75.90 & 74.70 & 65.60 & 67.20 \\
\hline $\mathrm{S}_{20} \times \mathrm{Sc}_{2} \times \mathrm{Ml}_{2}$ & 78.20 & 70.46 & 66.67 & 62.36 & 59.76 & 78.43 & 74.14 & 75.01 & 61.56 & 63.56 \\
\hline $\mathrm{S}_{20} \times \mathrm{Sc}_{2} \times \mathrm{Ml}_{3}$ & 77.28 & 68.15 & 64.62 & 60.02 & 54.31 & 78.43 & 73.45 & 62.85 & 57.62 & 55.44 \\
\hline $\mathrm{S}_{40} \times \mathrm{Sc}_{1} \times \mathrm{Ml}_{1}$ & 77.51 & 73.04 & 67.21 & 63.29 & 59.98 & 78.43 & 68.74 & 67.07 & 65.03 & 62.63 \\
\hline $\mathrm{S}_{40} \times \mathrm{Sc}_{1} \times \mathrm{Ml}_{2}$ & 77.51 & 70.61 & 65.01 & 61.43 & 54.62 & 78.43 & 68.0 & 70.91 & 61.80 & 58.57 \\
\hline $\mathrm{S}_{40} \times \mathrm{Sc}_{1} \times \mathrm{Ml}_{3}$ & 76.44 & 66.92 & 63.29 & 53 & 48.33 & 78.20 & 62.03 & 60.81 & 59.20 & 50.37 \\
\hline $\mathrm{S}_{40} \times \mathrm{Sc}_{2} \times \mathrm{Ml}_{1}$ & 78.69 & 75.22 & 71.54 & 67.46 & 64.87 & 78.43 & 77.11 & 76.08 & 66.12 & 66.80 \\
\hline $\mathrm{S}_{40} \times \mathrm{Sc}_{2} \times \mathrm{Ml}_{2}$ & 77.74 & 72.20 & 67.00 & 63.78 & 60.75 & 78.43 & 75.84 & 76.39 & 62.20 & 62.60 \\
\hline $\mathrm{S}_{40} \times \mathrm{Sc}_{2} \times \mathrm{Ml}_{3}$ & 77.11 & 68.99 & 65.37 & 61.90 & 55.22 & 78.20 & 75.94 & 64.76 & 58.07 & 56.39 \\
\hline $\mathrm{S}_{60} \times \mathrm{Sc}_{1} \times \mathrm{Ml}_{1}$ & 78.20 & 73.94 & 68.42 & 64.75 & 61.44 & 78.43 & 70.64 & 68.01 & 66.19 & 62.02 \\
\hline $\mathrm{S}_{60} \times \mathrm{Sc}_{1} \times \mathrm{Ml}_{2}$ & 77.53 & 71.88 & 66.40 & 62.01 & 55 & 78.43 & 69.41 & 70.85 & 63.02 & 59.45 \\
\hline $\mathrm{S}_{60} \times \mathrm{Sc}_{1} \times \mathrm{Ml}_{3}$ & 76.86 & 67.87 & 64.50 & 53.81 & 49.39 & 78.43 & 64.51 & 61.99 & 59.01 & 51.65 \\
\hline $\mathrm{S}_{60} \times \mathrm{Sc}_{2} \times \mathrm{Ml}_{1}$ & 78.95 & 76.86 & 73.37 & 69.74 & 66.93 & 78.47 & 72.40 & 77.07 & 66.20 & 66.70 \\
\hline $\mathrm{S}_{60} \times \mathrm{Sc}_{2} \times \mathrm{Ml}_{2}$ & 77.97 & 72.86 & 68.99 & 64.51 & 61.77 & 78.69 & 76.25 & 75.60 & 62.99 & 62.96 \\
\hline $\mathrm{S}_{60} \times \mathrm{Sc}_{2} \times \mathrm{Ml}_{3}$ & 77.97 & 69.58 & 66.53 & 62.24 & 56.56 & 78.43 & 75.47 & 65.38 & 59.89 & 58.28 \\
\hline $\mathrm{S}_{80} \times \mathrm{Sc}_{1} \times \mathrm{Ml}_{1}$ & 77.74 & 71.40 & 62.25 & 63.30 & 59.98 & 78.43 & 66.93 & 66.27 & 65.38 & 60.44 \\
\hline $\mathrm{S}_{80} \times \mathrm{Sc}_{1} \times \mathrm{Ml}_{2}$ & 77.51 & 68.86 & 64.50 & 60.09 & 54.62 & 78.43 & 70.03 & 65.73 & 61.60 & 58.04 \\
\hline $\mathrm{S}_{80} \times \mathrm{Sc}_{1} \times \mathrm{Ml}_{3}$ & 76.42 & 65.88 & 62.94 & 52.51 & 48.04 & 78.43 & 61.11 & 60.04 & 58.58 & 49.98 \\
\hline $\mathrm{S}_{80} \times \mathrm{Sc}_{2} \times \mathrm{Ml}_{1}$ & 78.43 & 72.69 & 70.00 & 65.88 & 64.26 & 78.43 & 76.44 & 77.09 & 65.66 & 66.03 \\
\hline $\mathrm{S}_{80} \times \mathrm{Sc}_{2} \times \mathrm{Ml}_{2}$ & 77.74 & 70.01 & 67.73 & 62.25 & 60.88 & 78.43 & 76.25 & 74.80 & 62.21 & 61.60 \\
\hline $\mathrm{S}_{80} \times \mathrm{Sc}_{2} \times \mathrm{Ml}_{3}$ & 77.07 & 68.07 & 65.00 & 60.31 & 54.31 & 78.43 & 75.86 & 63.78 & 59.28 & 57.03 \\
\hline $\mathrm{SD}$ & NS & 0.953 & NS & NS & NS & NS & NS & NS & NS & 2.391 \\
\hline
\end{tabular}


percentage of germination was obtained in the treatment $9.25 \%$ initial moisture content of seed kept in tin container and without inoculation. In 1998-99 the trend of retaining germination percentage was also similar. The results were in agreement with the result of Majhi and Bandopadhya (1993)

\section{Interaction of inoculation, storage container and initial moisture level on the germination percentage of stored seed}

The interaction of inoculation, storage container and initial moisture content of the seed was not significant in 1997-98 and 1998-99. The results are in agreement with the results of Majhi and Bandopadhya (1993).

Interaction of sulphur, inoculation, storage container and initial moisture percentage of seed on the germination percentage of stored seed

At all the intervals the interaction of all the four treatments was not significant in 199798 and 1998-99. Bhuiyan and Quashem (1983) reported similar results.

\section{References}

Bhuiyan M.S.A. and Quashem, A. (1983) Effect of containers on the viability of groundnut seed. Bangladesh J. Agric. 8(1-4) : 14-18.

Harrington, J.F. and Minges, P.A. (1973). Packaging seed for storage and shipment. Seed Sci. and Technol. 1 : 701-709.

Jayaraj, T. and Karivaratharaju, T.V. (1988). Storage potential of Rhizobium treated groundnut seeds at different moisture level in different containers. Madras Agril. J. 75(7-8) : 286-287.

Juangjun, D. and Sumran, S. (1991) Effect of calcium, magnesium and sulphur on the seed yield and seed quality of some large seeded groundnut cultivars. Proceeding of the 7th Oil Seed Conf. Thailand. : 468-475

Majhi, A. and Bandhopadhya, P.K. (1993). Vigour and viability of groundnut seed cv. JL-24 under different storage containers. Environ and Eco. 11(4) : 930-932.

Prasat, S. and Chaumsri, V.S. (1987) Effect of containers on the storability of groundnut seed. Proc. of the fourth Thailand National Groundnut Res. Meeting. : 511-519.

Puangthong, Yin, A. Lumduan, S. (1987) Effects of drying methods on germination of groundnut seeds. Proc. of the fifth National Groundnut Conf.: 539-542.

Puangthong, Yin, A. Lumduan, S. (1990) Effect of packaging materials on the storability of groundnut seed. Proc. of the fourth Thailand National groundnut res. meeting. : 521-525.

Vichai, H. Penkwan, C. Chintana, O. (1988). Study on the improvement on peanut quality. In Proc. of Sixth Thailand National Groundnut Meeting for 1986 : 641-643.

Received : May 25, 2006;

Accepted : April 29, 2007 